\title{
Sandflies (Diptera: Psychodidae) from caves of the quartzite Espinhaço Range, Minas Gerais, Brazil
}

\author{
Ricardo Andrade Barata/ ${ }^{+}$, Estefânia Conceição Apolinário \\ Laboratório de Parasitologia, Departamento de Ciências Biológicas, \\ Universidade Federal dos Vales do Jequitinhonha e Mucuri, Diamantina, MG, Brasil
}

\begin{abstract}
This study investigated the sandfly fauna of two quartzite caves in the Espinhaço Mountain Range, located in the municipality of Diamantina, state Minas Gerais. From August 2010-July 2011, entomological sampling was performed in the caves of Salitre and Monte Cristo with two HP light traps exposed in the photic and aphotic zones of each cave. The sandfly fauna consisted of 17 species, among which Lutzomyia cipoensis was predominant (54.76\%). The male/female ratio in the total captures was 1:2.5. The aphotic zone showed the highest frequency of specimens captured (65\%). A greater density of sandflies occurred during the summer (January-February), coinciding with the period of higher temperatures, humidity and rainfall. The presence of Lutzomyia longipalpis, Lutzomyia whitmani and Lutzomyia pessoai, proven or suspected vectors of leishmaniasis, is of concern because the area is visited by many tourists.
\end{abstract}

Key words: Lutzomyia - Phlebotomine - sandflies from caves - Espinhaço Range

The Espinhaço mountain range belongs to an extensive and continuous Precambrian orogenic zone (Almeida-Abreu \& Renger 2002) consisting of a group of mountains and plateaus located in the states of Minas Gerais (MG) and Bahia, Brazil. The range extends approximately $1.200 \mathrm{~km}$ in a predominantly north-south direction (Saadi 1995). In 2005, this group of mountains was considered by the United Nations Educational, Scientific and Cultural Organization as the seventh Brazilian biosphere reserve due to its enormous diversity and biological importance. This area is valuable due to its great number of caves and because it separates three important watersheds (Rio São Francisco, Rio Doce and Rio Jequitinhonha) and divides the savannah (Cerrado), Atlantic Forest and Caatinga biomes (Gontijo 2008).

Although MG has the largest number of caves in the country, studies regarding the survey of cave fauna have been concentrated in the state of São Paulo (SP) and conducted mainly in limestone caves. However, studies involving surveys of cave fauna have been concentrated in SP and have been conducted primarily in limestone caves (Gomes et al. 2000, Ferreira \& Horta 2001).

Furthermore, data on the sandflies of limestone, sandstone or quartzite caves are even less common and literature on sandflies is nonexistent for non-limestone caves, particularly quartzite caves. Given the recent expansion of ecotourism, regular monitoring of the cave areas that are used by visitors is crucially needed to facilitate preventive management of the transmission of leishmaniasis.

+ Corresponding author: ricbarata@hotmail.com

Received 15 June 2012

Accepted 8 August 2012
Therefore, this study aimed to identify the sandfly fauna of two quartzite caves, to investigate the relationship of the sandflies to climatic factors, to specify the seasonal distribution of the fauna and the transmission of leishmaniasis and to contribute to the knowledge of Brazilian biodiversity.

\section{MATERIALS AND METHODS}

Study area - The caves are located in the quartzite rocks of the Espinhaço Range, in the municipality of Diamantina, MG (Fig. 1). The caves named Gruta do Salitre (18 $16^{\circ} 47^{\prime}$ 'S 4332'10'W) and Gruta Monte Cristo (18¹7'49"S 4333'30'W) (Fig. 2A, B) are located $10 \mathrm{~km}$ from the city centre and $3 \mathrm{~km}$ from each other. They are predominantly horizontal, with two entrances and sandy soil with fallen overlapping rocks. The caves also contain perennial watercourses. These caves are constantly visited by tourists, researchers and other sightseers. Therefore, human activities, such as soil trampling, the removal of the neighbouring native forest, graffiti on the walls, fly ash resulting from fires, garbage accumulation and traces of recent saltpetre extraction, are evident.

Methods - Insects were captured with HP light traps (Pugedo et al. 2005) from August 2010-July 2011. The traps were exposed continuously for $40 \mathrm{~h} /$ month between 04:00 pm (day 1) and 08:00 am (day 3). Two traps were placed in each cave: one at its entrance (photic zone) and the other in the darkness (aphotic zone), approximately $50 \mathrm{~m}$ from the entrance. The specimens captured were transported to the Parasitological Laboratory of the Federal University of Jequitinhonha and Mucuri Valleys and then sacrificed by freezing. The males and females were placed in haemolytic tubes containing ethanol (70\%) and prepared and assembled on slides according to the technique of Langeron (1949). The taxonomic keys of Young and Duncan (1994) and Forattini (1973) were used to identify the sandfly species. The specimens with 


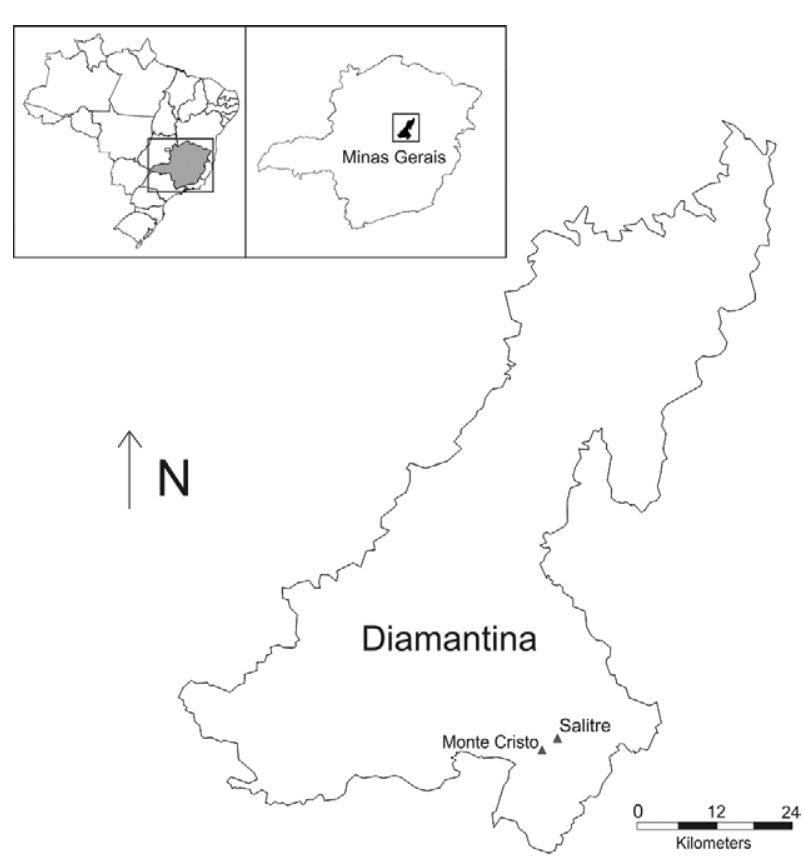

Fig. 1: geographical localization of the municipality of Diamantina, state of Minas Gerais, Brazil.

missing or damaged characters that prevented identification at the species level were identified as Lutzomyia spp. The females belonging to the genus Brumptomyia were not identified to the species level. The temperature and humidity were measured with a thermohygrometer at the capture site. The rainfall data were obtained from the Brazilian Meteorology Institute (inmet.gov.br/sim/ sonabra/convencionais.php).

Statistical analysis - We used the means of the climatic variables for the months of capture. A ShapiroWilk test was used to evaluate the normality of the data distribution (GraphPad Prism software v.5). The Spearman correlations between the climatic variables and the density of the sandflies were calculated and their statistical significance assessed $(\mathrm{p} \leq 0.05)$.

\section{RESULTS}

The sandfly fauna of the Gruta do Salitre and the Gruta Monte Cristo consists of 17 species: Brumptomyia avellari (Costa Lima, 1932), Brumptomyia cunhai (Mangabeira, 1942), Lutzomyia carmelinoi Ryan, Fraiha, Lainson and Shaw, 1986, Lutzomyia cipoensis Martins, Falcão and Silva, 1964, Lutzomyia evandroi (Costa Lima \& Antunes, 1936), Lutzomyia goiana Martins, Falcão and Silva, 1962, Lutzomyia ischyracantha Martins, Falcão and Silva, 1962, Lutzomyia longipalpis (Lutz \& Neiva, 1912), Lutzomyia longispina (Mangabeira, 1942), Lutzomyia oliveirai Martins, Silva and Falcão, 1970, Lutzomyia pessoai (Coutinho \& Barretto, 1940), Lutzomyia quinquefer (Dyar, 1929), Lutzomyia ramirezi Martins, Falcão, Silva and Miranda, 1982, Lutzomyia renei (Martins, Falcão \& Silva, 1957), Lutzomyia sordellii (Shannon \& Del Ponte, 1927), Lutzomyia whitmani (Antunes \& Coutinho, 1939) and one undescribed species. In total, 2,248 specimens were identified, of which 633 were males (28\%) and 1,615 females $(72 \%)$, with a ratio of one male to 2.5 females. The predominant species was $L u$. cipoensis, representing $54.76 \%$ of the total sandflies collected (Table).

The distribution of the sandflies captured in each cave and the climatic variables are represented in Fig. 3. The density of the sandflies in both caves showed positive correlations with the temperature, humidity and rainfall, with values of $\mathrm{p}=0.085, \mathrm{p}=0.931$ and $\mathrm{p}=0.378$, respectively. These values were not statistically significant at a level of $\mathrm{p} \leq 0.05$.

\section{DISCUSSION}

Cave ecotopes are commonly used by sandflies for shelter or as breeding sites (Galati et al. 2006) and a few studies have investigated the abundance and richness of sandflies in cave environments in Brazil. In the state of Amazonas (AM), Alves et al. (2011) identified 15 species of sandfly in three sandstone caves. Galati et al. (2010) examined the diversity of sandflies in caves in SP, consisting of 11 species. In Mato Grosso do Sul, Galati et al. $(2003,2006)$ captured many sandfly specimens in limestone caves in the Serra da Bodoquena. In MG, Barata et al. (2008) identified 14 species of sandfly in a limestone cave located in Cavernas do Peruaçu National Park.
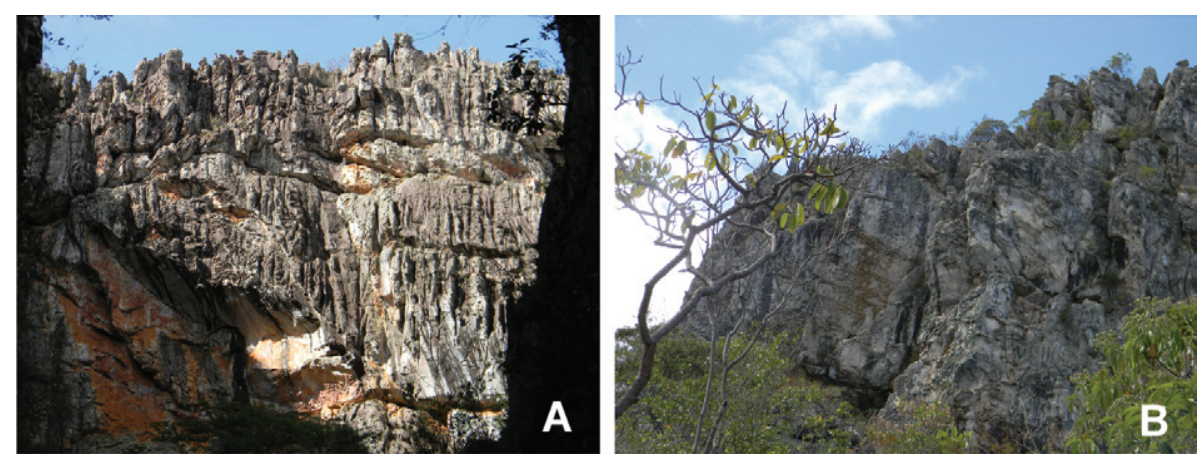

Fig. 2: partial view of Gruta do Salitre (A) and Gruta Monte Cristo located in quartzite rocks of the Espinhaço Range, municipality of Diamantina, state of Minas Gerais, Brazil. 
TABLE I

Phlebotomines captured in HP light traps according to the species, photic and aphotic zone and sex, in the Monte Cristo and Salitre Caves, municipality of Diamantina, state of Minas Gerais, Brazil, from August 2010-July 2011

\begin{tabular}{|c|c|c|c|c|c|c|c|c|c|}
\hline \multirow[b]{3}{*}{ Species } & \multicolumn{4}{|c|}{ Monte Cristo } & \multicolumn{4}{|c|}{ Salitre } & \multirow{3}{*}{$\begin{array}{l}\text { Total } \\
\mathrm{n}(\%)\end{array}$} \\
\hline & \multicolumn{2}{|c|}{ Photic } & \multicolumn{2}{|c|}{ Aphotic } & \multicolumn{2}{|c|}{ Photic } & \multicolumn{2}{|c|}{ Aphotic } & \\
\hline & q & $\hat{\sigma}$ & 우 & $\hat{0}$ & q & $\hat{\sigma}$ & q & 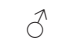 & \\
\hline Brumptomyia avellari & 0 & 0 & 0 & 0 & 0 & 0 & 0 & 1 & $1(0.04)$ \\
\hline Brumptomyia cunhai & 0 & 0 & 0 & 0 & 0 & 0 & 0 & 1 & $1(0.04)$ \\
\hline Lutzomyia carmelinoi & 4 & 6 & 2 & 0 & 1 & 1 & 2 & 0 & $16(0.71)$ \\
\hline Lutzomyia cipoensis & 71 & 22 & 16 & 12 & 167 & 70 & 673 & 200 & $1,231(54.76)$ \\
\hline Lutzomyia ischyracantha & 50 & 72 & 7 & 22 & 31 & 25 & 23 & 46 & $276(12.28)$ \\
\hline Lutzomyia evandroi & 5 & 3 & 0 & 1 & 0 & 0 & 0 & 0 & $9(0.40)$ \\
\hline Lutzomyia goiana & 0 & 0 & 0 & 0 & 0 & 1 & 2 & 0 & $3(0.13)$ \\
\hline Lutzomyia longipalpis & 9 & 15 & 6 & 12 & 2 & 1 & 0 & 0 & $45(2)$ \\
\hline Lutzomyia longispina & 0 & 0 & 0 & 0 & 0 & 0 & 1 & 0 & $1(0.04)$ \\
\hline Lutzomyia oliveirai & 16 & 14 & 89 & 76 & 0 & 1 & 2 & 6 & $204(9.07)$ \\
\hline Lutzomyia pessoai & 0 & 1 & 0 & 0 & 0 & 0 & 0 & 0 & $1(0.04)$ \\
\hline Lutzomyia quinquefer & 3 & 0 & 1 & 0 & 24 & 0 & 11 & 0 & $39(1.73)$ \\
\hline Lutzomyia ramirezi & 1 & 0 & 5 & 0 & 0 & 0 & 0 & 0 & $6(0.27)$ \\
\hline Lutzomyia renei & 1 & 0 & 0 & 0 & 0 & 0 & 0 & 0 & $1(0.04)$ \\
\hline Lutzomyia sordellii & 0 & 0 & 1 & 0 & 0 & 0 & 0 & 0 & $1(0.04)$ \\
\hline Lutzomyia whitmani & 1 & 0 & 0 & 0 & 0 & 0 & 0 & 0 & $1(0.04)$ \\
\hline Brumptomyia spp & 0 & 0 & 0 & 0 & 0 & 0 & 1 & 0 & $1(0.04)$ \\
\hline Lutzomyia spp & 2 & 3 & 3 & 0 & 10 & 1 & 10 & 1 & $30(1.33)$ \\
\hline Lutzomyia sp. (undescribed) & 32 & 0 & 111 & 13 & 110 & 3 & 109 & 3 & $381(16.95)$ \\
\hline Sub-total & 195 & 136 & 241 & 136 & 345 & 103 & 834 & 258 & $2,248(100)$ \\
\hline Total & & & & & & & & & - \\
\hline
\end{tabular}

According to the results shown in Table, captures of insects in the aphotic zone $(65 \%)$ were predominant. However, almost all of the species considered were captured both in the photic and aphotic zones. Considerations of the behaviour that enables the completion of the life cycle either within or outside the caves suggest that these species are troglophiles in terms of Schinner-Racovitza's system (Holsinger \& Culver 1988) for cave organisms. This hypothesis was also suggested by Galati et al. (2003).

In general, the presence of sandflies in these caves appears to be related to the presence of bats, rodents, birds and lizards, which can serve as blood sources for the sandflies. Analyses of the gut contents of engorged females will be performed to identify the blood sources. Moreover, the large amount of guano inside the caves may serve as a breeding site for sandflies, as shown by Alves et al. (2011).

Caves have unique characteristics, including high humidity, stable temperatures and the risk of starvation due to scarce food resources (Auler \& Zogbi 2005, White \& Culver 2005). These features most likely influence the distribution of organisms in the cave environment. The two caves showed a greater number of sand- flies in the summer (January-February), coinciding with the period of higher temperatures, humidity and rainfall. In contrast, a decrease in the density of these insects was found during the coldest and driest months. This pattern of seasonality has also been reported in most of the studies on sandflies in the endemic areas for leishmaniasis in MG (Barata et al. 2004, 2011).

The analysis of both caves showed that the distribution of sandflies in Gruta Monte Cristo was more nearly homogeneous during the study period than in Gruta do Salitre (Fig. 3). The reason for this finding may be that the former cave is less known and less accessible than the latter. The anthropogenic influence on Gruta Monte Cristo would also be lower for this reason. Consequently, trampling and vandalism appear to cause less disturbance to the sandfly breeding sites in Gruta Monte Cristo throughout the year. These factors can most likely explain the lower number of species found in Gruta do Salitre (11 species) than in Gruta Monte Cristo (13 species).

Although Lu. longipalpis is considered highly urbanised, with a high degree of synanthropy, this species has also been collected in the wild environment of caves in Diamantina, as observed by Galati et al. (2003). Lu. 

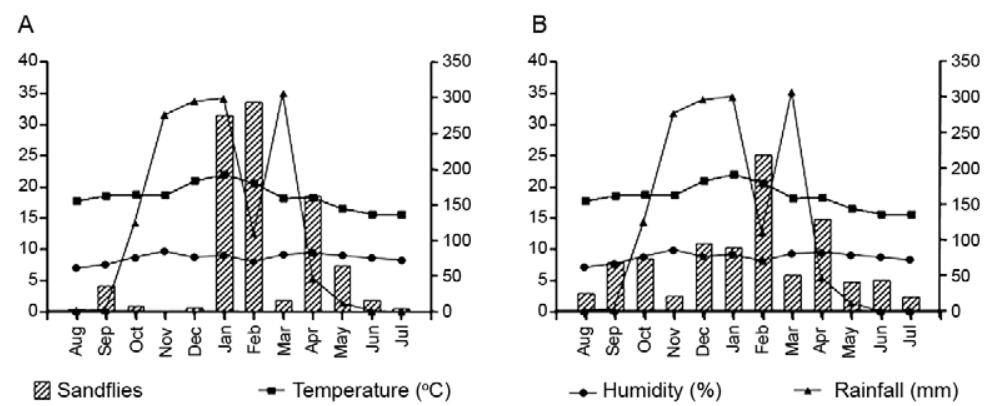

Fig. 3: mensal distribution of phlebotomine sandflies (columns) and climatic conditions in Gruta do Salitre (A) and Gruta Monte Cristo (B), municipality of Diamantina, state of Minas Gerais, Brazil, from August 2010-July 2011.

whitmani, a vector of Leishmania braziliensis in southeastern Brazil (Mayrink et al. 1979, Rocha et al. 2010), was recorded in small numbers in this study, as was $L u$. pessoai, a species suspected of transmitting the agent of cutaneous leishmaniasis (Forattini et al. 1972). The other species collected in this study are not currently of epidemiological interest in terms of the transmission of leishmaniasis.

Several recent studies have contributed to the knowledge of the biodiversity of Brazilian caves. Alves et al. (2008) described Lutzomyia maruaga, which was captured in the aphotic zone of a sandstone cave in AM. Carvalho et al. (2010) described Martinsmyia reginae, captured in a cave in the state of Tocantins, and Carvalho et al. (2011a) described Evandromyia spelunca, found in a cave in Lassance, MG. In the present study, an undescribed species (Lutzomyia sp.) was also captured in large numbers (16.9\%), as shown in Table.

In this context, it is essential to implement educational programs and to conduct increased monitoring of the cave environment in association with a management plan to assure conservation actions and define regulations for access to caves, particularly during the months of higher sandfly densities. The presence of vectors of the leishmaniasis agent is of concern due to the increased volume of tourists and requires greater attention from the local ecotourism organisations.

\section{REFERENCES}

Almeida-Abreu PA, Renger FE 2002. Serra do Espinhaço Meridional: um orógeno de colisão do Mesoproterozóico. Revista Brasileira de Geociências 32: 1-14.

Alves VR, de Freitas RA, Barrett T 2008. Lutzomyia maruaga (Diptera: Psychodidae), a new bat-cave sand fly from Amazonas, Brazil. Mem Inst Oswaldo Cruz 103: 251-253.

Alves VR, de Freitas RA, Santos FL, Barrett TV 2011. Diversity of sandflies (Psychodidae: Phlebotominae) captured in sandstone caves from Central Amazonia, Brazil. Mem Inst Oswaldo Cruz 106: 353-359.

Auler A, Zogbi L 2005. Espeleologia - noções básicas, Redespeleo Brasil, São Paulo, 104 pp.

Barata RA, da Silva JCF, Fortes-Dias CL, da Costa RT, Fortes-Dias CL, da Silva JC, de Paula EV, Prata A, Monteiro EM, Dias ES 2004. Phlebotomine sand flies in Porteirinha, an area of Ameri- can visceral leishmaniasis transmission in the state of Minas Gerais, Brazil. Mem Inst Oswaldo Cruz 99: 481-487

Barata RA, Antonini Y, Macedo CG, Costa DC, Dias ES 2008. Flebotomíneos do Parque Nacional Cavernas do Peruaçu, Minas Gerais, Brasil. Neotrop Entomol 37: 226-228.

Barata RA, Paz GF, Bastos MC, Andrade RCO, Barros DCM, LaraSilva FO, Michalsky EM, Pinheiro AC, Dias ES 2011. Phlebotomine sandflies (Diptera: Psychodidae) in Governador Valadares, a transmission area for American tegumentary leishmaniasis in state of Minas Gerais, Brazil. Rev Soc Bras Med Trop 44: 136-139.

Carvalho GML, Brazil RP, Sanguinette CC, Andrade-Filho JD 2010. Description of a new phlebotomine species, Martinsmyia reginae sp. nov. (Diptera: Psychodidae: Phlebotominae) from a cave in the state of Tocantins Brazil. Mem Inst Oswaldo Cruz 105: 336-340.

Carvalho GML, Brazil RP, Sanguinette CC, Andrade-Filho JD 2011a. Description of Evandromyia spelunca, a new phlebotomine species of the cortelezzii complex, from a cave in Minas Gerais state, Brazil (Diptera: Psychodidae: Phlebotominae). Parasit Vectors 4: 158.

Carvalho GM, Vasconcelos FB, Silva DG, Botelho HA, AndradeFilho JD 2011b. Diversity of phlebotomine sand flies (Diptera: Psychodidae) in Ibitipoca State Park, Minas Gerais, Brazil. J Med Entomol 48: 764-9.

Ferreira RL, Horta LCS 2001. Impactos sobre comunidades de invertebrados em cavernas brasileiras. Rev Bras Biol 61: 7-17.

Forattini OP 1973. Entomologia médica. Psychodidae. Phlebotominae. Leishmaniose. Bartonelose, Vol. IV, Edgard Blücher, São Paulo, 658 pp.

Forattini OP, Pattoli DBG, Rabello EX, Ferreira OA 1972. Infecção natural de flebotomlineos em foco enzoótico de leishmaniose tegumentar no estado de São Paulo, Brasil. Rev Saude Publica 6: 431-433.

Galati EAB, Nunes VLB, Boggiani PC, Dorval MEC, Cristaldo G, Rocha HC, Oshiro ET, Gonçalves-de-Andrade RM, Naufel G 2003. Phlebotomines (Diptera: Psychodidae) in caves of the Serra da Bodoquena, Mato Grosso do Sul state, Brazil. Rev Bras Entomol 47: 283-296.

Galati EAB, Nunes VLB, Boggiani PC, Dorval MEC, Cristaldo G, Rocha HC, Oshiro ET, Dasmaceno-Júnior GA 2006. Phlebotomines (Diptera: Psychodidae) in forested areas of the Serra da Bodoquena, state of Mato Grosso do Sul, Brazil. Mem Inst Oswaldo Cruz 101: 175-193.

Galati EAB, Marassá AM, Gonçalves-Andrade RM, Consales CA, Bueno EFM 2010. Phlebotomines (Diptera, Psychodidae) in the Ribeira Valley speleological province. 1. Parque Estadual Intervales, state of São Paulo, Brazil. Rev Bras Entomol 54: 311-321. 
Gomes FTMC, Ferreira RL, Jacobi CM 2000. Comunidade de artrópodes de uma caverna calcária em área de mineração: composição e estrutura. Revista Brasileira de Zoociências 2: 77-96.

Gontijo BM 2008. Uma geografia para a Cadeia do Espinhaço. Megadiversidade 4: 7-15.

Holsinger R, Culver DC 1988. The invertebrate cave fauna of Virginia and a part of eastern Tennessee: zoogeography and ecology. Brimleyana 14: 1-162.

Langeron M 1949. Précis de microscopie, Masson et Cie, Libraires de L'Académie de Medicine, Paris, 1 pp.

Mayrink W, Williams P, Coelho MV, Dias M, Martins AV, Magalhães PA, Costa CA, Falcão AR, Melo MN, Falcão AL 1979. Epidemiology of dermal leishmaniasis in the Rio Doce Valley, state of Minas Gerais, Brazil. Ann Trop Med Parasitol 73: 123-137.
Pugedo H, Barata RA, França-Silva JC, Silva JC, Dias ES 2005. HP: um modelo aprimorado de armadilha luminosa de sucção para a captura de pequenos insetos. Rev Soc Bras Med Trop 38: 70-72.

Rocha LS, Falqueto A, dos Santos CB, Ferreira AL, Graça GC, Grimaldi-Jr G, Cupolillo E 2010. Survey of natural infection by Leishmania in sand fly species collected in southeastern Brazil. Trans R Soc Trop Med 104: 461-466.

Saadi A 1995. A geomorfologia da Serra do Espinhaço em Minas Gerais e de suas margens. Geonomos 3: 41-63.

White WB, Culver DC 2005. Definition of cave. In DC Culver, WB White (orgs.), Encyclopedia of cave, Elsevier, Amsterdam, 654 pp.

Young DG, Duncan MA 1994. Guide to the identification and geographic distribution of Lutzomyia sand flies in Mexico, the West Indies, Central and South America (Diptera: Psychodidae). Mem Am Entomol Inst 54: 1-881. 